\title{
The Character of Dual Site Adsorbent on Coal Fly Ash Toward Benzene Adsorption
}

\author{
Widi Astuti ${ }^{1}$, Endang Tri Wahyuni ${ }^{2}$, Agus Prasetya ${ }^{3}$, I Made Bendiyasa ${ }^{3}$
}

\begin{abstract}
Large quantities of coal fly ash (CFA) are produced during combustion of coal in the production of electricity. Most of this ash has not been widely used. CFA is mainly composed of some oxides including $\mathrm{Al}_{2} \mathrm{O}_{3}$ and $\mathrm{SiO}_{2}$ having active site and unburned carbon as a mesopore that enables it to act as a dual site adsorbent. To get different characters of dual site, CFA was sieved using 150 mesh size, heated at $400^{\circ} \mathrm{C}$ and reacted with sodium hydroxide solution. Furthermore, CFA was used as adsorbent of benzene in aqueous solutions. Equilibrium data were evaluated by single site and dual site isotherm models. It can be concluded that single site model yielded excellent fit with equilibrium data of benzene. The values of maximum concentration of adsorbate in solid surface $\left(\mathrm{C}_{\mu \mathrm{m}}\right)$ and Langmuir constant $\left(\mathrm{K}_{\mathrm{L}}\right)$ are affected by $[\mathrm{Si}+\mathrm{Al}] / \mathrm{C}$ ratio in CFA. The increase of $[\mathrm{Si}+\mathrm{Al}] / \mathrm{C}$ ratio causes a decrease of $\mathrm{q}_{\mathrm{m}}$ and $\mathrm{K}_{\mathrm{L}}$ values.
\end{abstract}

Keywords : coal fly ash, adsorption, benzene

\section{Introduction}

Large quantities of CFA are produced during the combustion of coal in the production of electricity. In Indonesia, more than 1 million tons of CFA is being generated annually [1]. Most of this ash is used in low level applications including landfill. Two approaches have been made for proper utilization of CFA, either to reduce the cost of disposal or to minimize the environmental impact. One application of CFA is used as an adsorbent [2]. CFA is composed of some oxides including $\mathrm{Al}_{2} \mathrm{O}_{3}, \mathrm{SiO}_{2}$ having active site and unburned carbon (C) as a mesopore material [3] that enables it to act as a dual site adsorbent.

On the other side, benzene is one of the toxic pollutant and carcinogenic compound [4] used as a raw material in the petrochemical industry [5]. Several methods have evolved over the years on the removal of it in industrial waste water. However, adsorption is an appropriate method to remove benzene at a low concentration level. Many adsorbents have been tested to remove it from aqueous solutions including activated carbon [5]. However, to improve the efficiency of adsorption process, it is necessary to develop an adsorbent that is cheaper but has high adsorption capacity including CFA. In this paper, the effect of dual site on CFA toward benzene adsorption is discussed. 


\section{Material and methods}

\subsection{Sample Preparation and Characterization}

Benzene in extra pure grade were purchased through Merck. While, CFA was obtained from Tanjungjati power plant, Jepara, Indonesia. Before any treatment, CFA was washed with distilled water and dried. To study dual site character of CFA toward benzene adsorption, it is used CFA having $[\mathrm{Si}+\mathrm{Al}] / \mathrm{C} \approx 0.5,[\mathrm{Si}+\mathrm{Al}] / \mathrm{C} \approx 2$ and $[\mathrm{Si}+\mathrm{Al}] / \mathrm{C} \approx$ 90, obtained from sieving of CFA using 100 mesh size, reaction of CFA with sodium hydroxide $3 \mathrm{M}$ at temperature of $60^{\circ} \mathrm{C}$ for 2 hours; and heating of $\mathrm{CFA}$ at $400{ }^{\circ} \mathrm{C}$, respectively. Furthermore, the chemical compositions of CFA was analyzed using x-ray fluorescence (XRF). While crystallinity and morphology of CFA were analyzed using XRD (Schimadzu XRD-6000) and SEM (JEOL, Japan), respectively. Surface areas and pore structures of the prepared samples were established from nitrogen adsorption isotherm as measured at $77 \mathrm{~K}$ by means of a NOVA 1200 microanalyzer (QUANTACHROME). The surface area was calculated using BET equation while the pore size distribution was established through the use of $\mathrm{BJH}$ method.

\subsection{Batch Adsorption Experiment}

Each of CFA (4g) was put into an erlenmeyer filled $230 \mathrm{~mL}$ of benzene solution. The erlenmeyer contained the mixture was placed in a waterbath at $28^{\circ} \mathrm{C}$ and shaken mechanically for 72 hours. Subsequently, suspended solid was filtered and the filtrate was analyzed to determine benzene concentration using gas chromatography (GC).

\subsection{Isotherm Models}

Isotherm models used in this study are a single site and dual site which is modificated from langmuir and freundlich isotherm. Models used in this study are single-site langmuir ( $1^{\text {st }}$ model), single site freundlich ( $2^{\text {nd }}$ model $)$, dual site langmuir-langmuir ( $3^{\text {rd }}$ model), dual site freundlich-freundlich ( $4^{\text {th }}$ model), dual site langmuir-freundlich $\left(5^{\text {th }}\right.$ model $)$ and dual site freundlich-langmuir ( $6^{\text {th }}$ model $)$.

\subsection{1. $1^{\text {st }}$ model : single site langmuir}

In this model, contribution of active site in the benzene adsorption is assumed very small, so it can be ignore. Adsorption occurs on the unburned carbon having homogeneous energy. Other assumption, it is localized adsorption and each site only bind one atom or molecule. In addition, the interaction between the adsorbate molecules is ignored. The equation of $1^{\text {st }}$ model is describes as :

$$
C_{\mu}=C_{\mu m} \frac{K_{L} C_{e}}{1+K_{L} C_{e}}
$$

where $C_{\mu m}$ is maximum concentration of adsorbate in solid surface at equilibrium

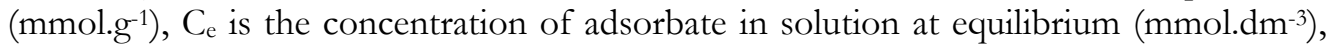
$\mathrm{C}_{\mu}$ concentration of adsorbate in solid surface at equilibrium $\left(\mathrm{mmol}^{-1}\right)$ and $\mathrm{K}_{\mathrm{L}}$ is the Langmuir constant related to the adsorption sites affinity $\left(\mathrm{dm}^{3} \cdot \mathrm{mmol}^{-1}\right)$.

\subsection{2. $2^{\text {nd }}$ model : single site freundlich}

In this model, contribution of active site in the adsorption is assumed very small, so it can be ignored. Adsorption occurs on unburned carbon having heterogeneous energy. 
Other assumption, it is localized adsorption and no interaction between adsorbate molecules. The equation of $2^{\text {nd }}$ model is described as:

$$
C_{\mu}=K_{F} C_{e}^{1 / n}
$$

where $K_{L}\left(\mathrm{mmol} \cdot \mathrm{g}^{-1}\right)$ is Freundlich constant, and $1 / \mathrm{n}\left(\mathrm{dm}^{3} \cdot \mathrm{g}^{-1}\right)$ is heterogeneity factor.

\subsection{3. $3^{\text {rd }}$ model : dual site langmuir - langmuir isotherm}

In this model, active sites and unburned carbon contribute to the adsorption. Active sites and unburned carbon are considered to the different patch having different energy levels. Each patch is independent and there is no interaction between patches. While, at the same patch, site has homogeneous energy distribution. Adsorbate molecules is adsorbed only by one site and there is no interaction between adsorbate molecules. $3^{\text {rd }}$ model is described as :

$$
C_{\mu}=C_{\mu m 1} \frac{K_{L 1} C_{e}}{1+K_{L 1} C_{e}}+C_{\mu m 2} \frac{K_{L 2} C_{e}}{1+K_{L 2} C_{e}}
$$

where '1' indicates site 1 (unburned carbon) and '2' indicates site 2 (active sites). $K_{\mathrm{L} 1}, \mathrm{~K}_{\mathrm{L} 2}$, $\mathrm{C}_{\mu \mathrm{m} 1}, \mathrm{C}_{\mu \mathrm{m} 2}$ can be determined by trial and error method which gives a minimum Sum of Square Error (SSE).

\subsection{4. $4^{\text {th }}$ model : dual site freundlich - freundlich isotherm}

In this model, active sites and unburned carbon contribute to the adsorption. Active sites and unburned carbon are considered to the different patch having different energy levels. Each patch is independent and there is no interaction between the patches. While, the same patch has heterogeneous energy distribution. Adsorbate molecules is adsorbed only by one site and there is no interaction between adsorbate molecules. The model is described as :

$$
C_{\mu}=K_{F 1} \cdot C_{e}^{1 / n 1}+K_{F 2} \cdot C_{e}^{1 / n 2}
$$

where ' 1 ' indicates the site 1 (unburned carbon) and ' 2 ' indicates the site 2 (active sites). $\mathrm{K}_{\mathrm{F} 1}, \mathrm{~K}_{\mathrm{F} 2}, \mathrm{n}_{1}, \mathrm{n}_{2}$ can be determined by trial and error method which gives a minimum SSE.

\subsection{5. $5^{\text {th }}$ model: dual site langmuir - freundlich isotherm}

In this model, active sites and unburned carbon contribute to the adsorption. Active sites and unburned carbon are considered to the different patch having different energy levels. Each patch is independent and there is no interaction between the patches. Unburned carbon patch has a homogeneous distribution energy, while active sites patch has heterogeneous distribution energy. The $5^{\text {th }}$ model is described as

$$
C_{\mu}=C_{\mu m 1} \frac{K_{L 1} C_{e}}{1+K_{L 1} C_{e}}+K_{F 2} \cdot C_{e}^{1 / n 2}
$$

where ' 1 ' indicates the site 1 (unburned carbon) and ' 2 ' indicates the site 2 (active sites). $\mathrm{K}_{\mathrm{L} 1}, \mathrm{C}_{\mu \mathrm{m} 1}, \mathrm{~K}_{\mathrm{F} 2}, \mathrm{n}_{2}$ can be determined by trial and error method which gives a minimum SSE. 


\subsection{6. $6^{\text {th }}$ model: dual site freundlich isotherm - langmuir}

In this model, active sites and unburned carbon contribute to the adsorption. Active sites and unburned carbon are considered to the different patch having different energy levels. Each patch is independent and there is no interaction between the patches. Unburned carbon patch has a heterogeneous distribution energy, while active sites patch has homogeneous distribution energy. $6^{\text {th }}$ model is described as :

$$
C_{\mu}=K_{F 1} \cdot C_{e}^{1 / n 1}+C_{\mu m 2} \frac{K_{L 2} C_{e}}{1+K_{L 2} C_{e}}
$$

where ' 1 ' indicates the site 1 (unburned carbon) and ' 2 ' indicates the site 2 (active sites). $\mathrm{K}_{\mathrm{F} 1}, \mathrm{n}_{1}, \mathrm{~K}_{\mathrm{L} 2}, \mathrm{C}_{\mu \mathrm{m} 2}$ can be determined by trial and error method which gives a minimum SSE.

\section{Results and Discussion}

\subsection{Characters of CFA}

The chemical compositions of original CFA obtained from x-ray fluorescence (XRF) analysis is presented in Table 1 [6]. It shows that the major component of CFA are silica $\left(\mathrm{SiO}_{2}\right)$, alumina $\left(\mathrm{Al}_{2} \mathrm{O}_{3}\right)$ and carbon. While, the comparation of [Si+Al]/C ratio of CFA used in this study is described in Table 2. To confirm the existence of silica and alumina, CFA was also analyzed using x-ray diffraction (XRD). The XRD pattern of original CFA can be seen in Figure 1 [6].

Table 1 Composition of Original CFA

\begin{tabular}{ll}
\hline Component & Content (mass \%) \\
\hline $\mathrm{SiO}_{2}$ & 36.47 \\
$\mathrm{Al}_{2} \mathrm{O}_{3}$ & 19.27 \\
$\mathrm{CaO}$ & 6.56 \\
$\mathrm{MgO}$ & 2.94 \\
$\mathrm{Fe} \mathrm{O}_{3}$ & 10.74 \\
$\mathrm{MnO}$ & 0.07 \\
$\mathrm{Na} 2$ & 1.76 \\
$\mathrm{~K}_{2} \mathrm{O}$ & 1.77 \\
$\mathrm{CuO}$ & 0.01 \\
$\mathrm{As}_{2} \mathrm{O}_{3}$ & 0.01 \\
$\mathrm{P}_{2} \mathrm{O}_{5}$ & 0.25 \\
$\mathrm{SO}_{3}$ & 1.04 \\
$\mathrm{Carbon}$ & 19.11 \\
\hline
\end{tabular}

Table $2 \mathrm{Si}, \mathrm{Al}$ and $\mathrm{C}$ content of $\mathrm{CFA}$

\begin{tabular}{cr}
\hline $\begin{array}{c}{[\mathrm{Si}+\mathrm{Al}] / \mathrm{C} \text { ratio of }} \\
\mathrm{CFA}\end{array}$ & Component \\
\hline 0.5 & $\mathrm{Si}$ \\
& $\mathrm{Al}$ \\
2.0 & $\mathrm{C}$ \\
& $\mathrm{Si}$ \\
& $\mathrm{Al}$ \\
90 & $\mathrm{C}$ \\
& $\mathrm{Si}$ \\
& $\mathrm{Al}$ \\
$\mathrm{C}$
\end{tabular}

Table 3 Characters of the coal fly ash

\begin{tabular}{cll}
\hline $\begin{array}{c}[\mathrm{Si}+\mathrm{A}]] / C \text { ratio of } \\
\mathrm{CFA}\end{array}$ & Characters & Value \\
\hline \multirow{2}{*}{0.5} & Total crystallinity, \% & 100.0 \\
& Specific surface area, $\mathrm{m}^{2} \cdot \mathrm{g}^{-1}$ & 15.7 \\
\multirow{2}{*}{2.0} & Total crystallinity, \% & 65.0 \\
& Specific surface area, $\mathrm{m}^{2} \cdot \mathrm{g}^{-1}$ & 80.3 \\
\multirow{2}{*}{90} & Total crystallinity, \% & 88.2 \\
& Specific surface area, $\mathrm{m}^{2} \cdot \mathrm{g}^{-1}$ & 9.7 \\
\hline
\end{tabular}


It shows that CFA contains crystalline phases including quartz $\left(\mathrm{SiO}_{2}\right)$, mullite $\left(3 \mathrm{Al}_{2} \mathrm{O}_{3} .2 \mathrm{SiO}_{2}\right)$ and amorphous components.

Quantitatively, crystallinity of quartz and mullite are calculated using comparation between intensity of quartz or mullite peaks in treated CFA with standard quartz or mullite peaks as can be written [6] :

$$
\text { crystallinity }=\frac{I_{A}}{I_{o}} \times 100 \%
$$

where $I_{A}$ is intensity of quartz or mullite peaks in treated CFA and $I_{O}$ is intensity of standard quartz or mullite peaks. Total cystallinity is the summation of quartz, mullite and hydroxysodalite that may be composed during the treatment. Total crystallinity of CFA used in this study is described in Table 3. CFA having [ $\mathrm{Si}+\mathrm{Al}] / \mathrm{C}$ ratio of 2.0 obtained from reaction of CFA with sodium hydroxide has the lowest total crystallinity and the highest specific surface area. It indicates formation of amorphous material caused by the damages of quartz and mullite after reaction of CFA with sodium hydroxide forms holes in CFA surface, as can be seen in Figure 2. CFA having [Si+Al]/C ratio of 0.5 comprises smooth spherical particles as can be seen in Figure $2 \mathrm{a}$, while CFA having [Si+Al]/C ratio of 2.0 has rougher surface and full of holes, as can be seen in Figure 2b.

Fig. 1 XRD patterns of original coal fly ash Symbols : Q-quart», M-mullite

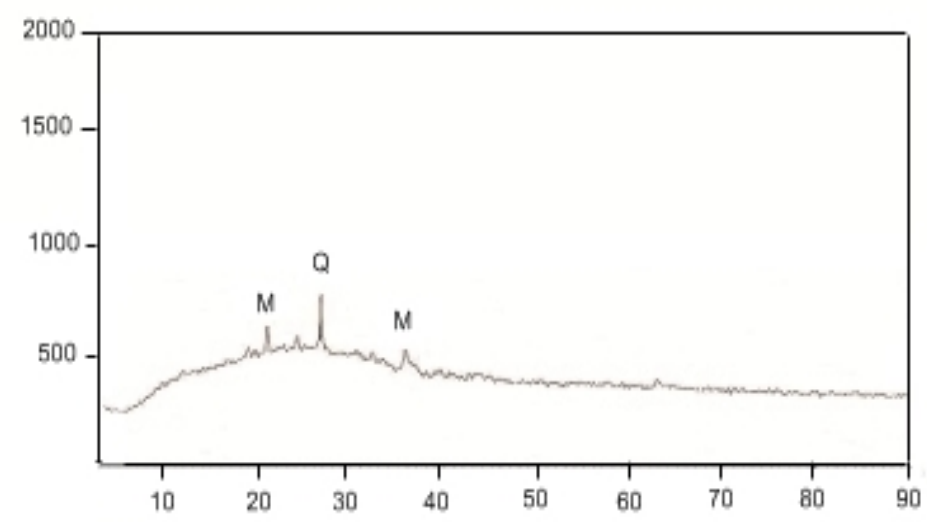

Fig. 2 SEM micrograph of CFA having (a) $[S i+A l] / C$ ratio $\approx 0.5$ (b) $[S i+A l] / C$ ratio $\approx 2.0$
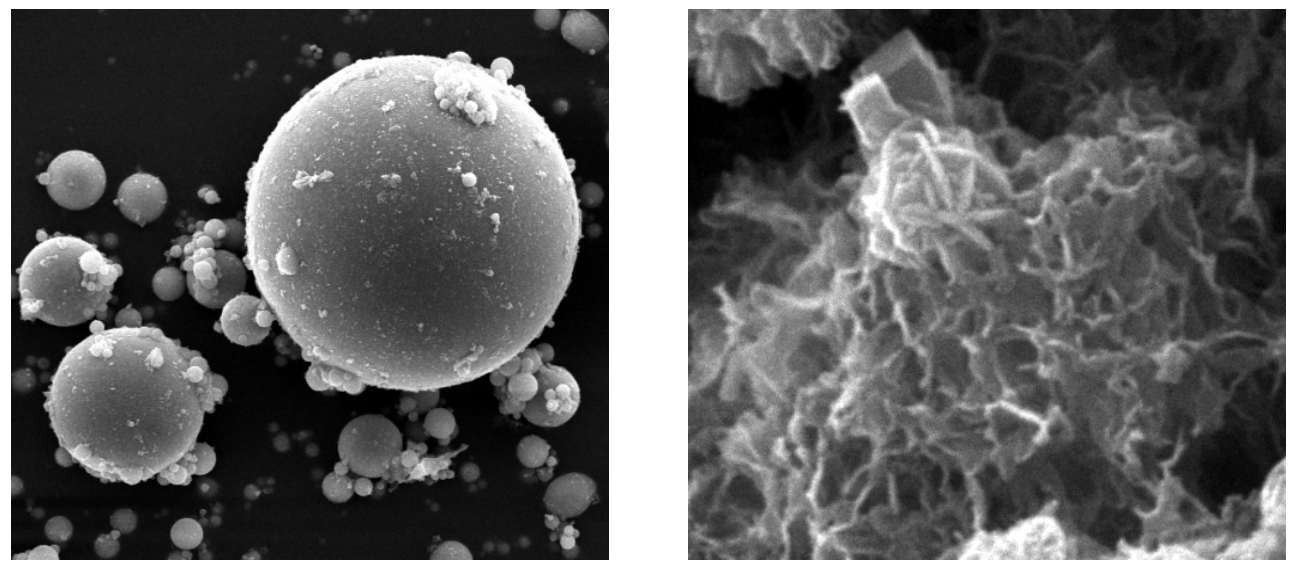


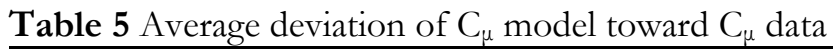

\begin{tabular}{ccccc}
\hline & & \multicolumn{3}{c}{ Average deviation of $\mathrm{C}_{\mu}$ model toward $\mathrm{C}_{\mu}$ data $(\%)$} \\
\cline { 3 - 5 } & & {$[\mathrm{Si}+\mathrm{Al}] / \mathrm{C} \approx 0.5$} & $\mathrm{C} \approx 2$ & {$[\mathrm{Si}+\mathrm{Al}] /$} \\
\hline $1^{\text {st }}$ & model & 4.2 & 5.9 & 9.2 \\
$2^{\text {nd }}$ & model & 33.8 & 22.6 & 30.1 \\
$3^{\text {rd }}$ & model & 5.0 & 7.0 & 15.5 \\
$4^{\text {th }}$ & model & 29.9 & 25.2 & 13.7 \\
$5^{\text {th }}$ & model & 4.8 & 6.3 & 9.7 \\
$6^{\text {th }}$ & model & 8.3 & 8.9 & 13.9 \\
\hline
\end{tabular}

\subsection{Adsorption of Benzene}

Adsorption of benzene is presented in Fig. 3. CFA having higher unburned carbon content $([\mathrm{Si}+\mathrm{Al}] / \mathrm{C}$ ratio $\approx 0.5)$ has higher adsorption capacity. It shows that the unburned carbon contributes to the benzene adsorption. Unburned carbon is a nonpolar material so it can adsorb benzene which is also a non-polar compounds. While, active site is a polar material so it is difficult to adsorb benzene. Interaction between unburned carbon and benzene involves Van der Waals forces.

To ensure adsorption properties of benzene, benzene is desorbed from CFA that had adsorbed benzene using distilled water [7]. If benzene can be desorbed by distilled water, it indicates that the adsorption force is weak. The desorption results is presented in Table 4. Data in Table 4 shows that almost all benzene can be desorbed by distilled water. It confirms that the adsorption properties is weak. Adsorption occurs at pore of unburned carbon through Van der Waals interaction and no involves chemical binding as has already been explained earlier.

Fig. 3 Adsorption of benzene $\left(\right.$ dose $=4 \mathrm{gram} / 230 \mathrm{~cm}^{3}$, $p H=7$, temperature $=28^{\circ} \mathrm{C}$, time $=72$ hours)

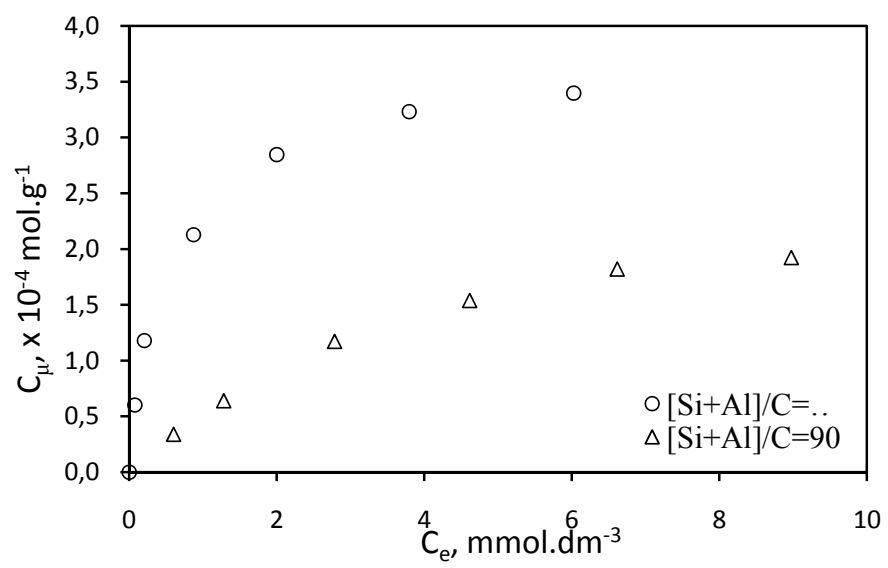

Table 4 The amount of benzene adsorbed and desorbed by CFA having varied unburned carbon content

\begin{tabular}{lll}
\hline & \multicolumn{2}{l}{$[\mathrm{Si}+\mathrm{Al}] / \mathrm{C}$ ratio of CFA } \\
& 90 & 0.5 \\
\hline benzena adsorbed, mmol.g-1 & 0.1821 & 0.3231 \\
benzena desorbed, mmol.g-1 & 0.1773 & 0.3156 \\
benzena desorbed, $\%$ & 97.4 & 97.7 \\
\hline Note & initial concentration of adsoption process $=800 \mathrm{mo} \mathrm{dm}^{3}$ &
\end{tabular}

Note : initial concentration of adsoption process $=800 \mathrm{mg}^{\circ} \mathrm{dm}^{3}$ 


\subsection{Isotherm Models}

The average deviation between $C_{\mu}$ model and $C_{\mu}$ data is described in Table 5 . Data in Table 5 shows that $1^{\text {st }}$ model is seen in accordance with experimental data for all CFA because it has the lowest average deviation. Benzene can only be adsorbed by unburned carbon through Van der Waals interaction as has already been explained earlier. Thus, there is suitability between experimental data with the $1^{\text {st }}$ model assumption. Comparation between $1^{\text {st }}, 2^{\text {nd }}, 3^{\text {rd }}$ and $4^{\text {th }}$ models with experimental data is described in Figure 4, while the value of maximum concentration of adsorbate in solid surface at equilibrium $\left(\mathrm{C}_{\mu \mathrm{m})}\right.$ and Langmuir constant $\left(\mathrm{K}_{\mathrm{L}}\right)$ is described in Table 6 .

Fig. 4 Isotherm models for benzene : (a) $1^{\text {st }}$ model (b) $2^{\text {nd }}$ model (c) $3^{\text {rd }}$ model (d) $4^{\text {th }}$ model
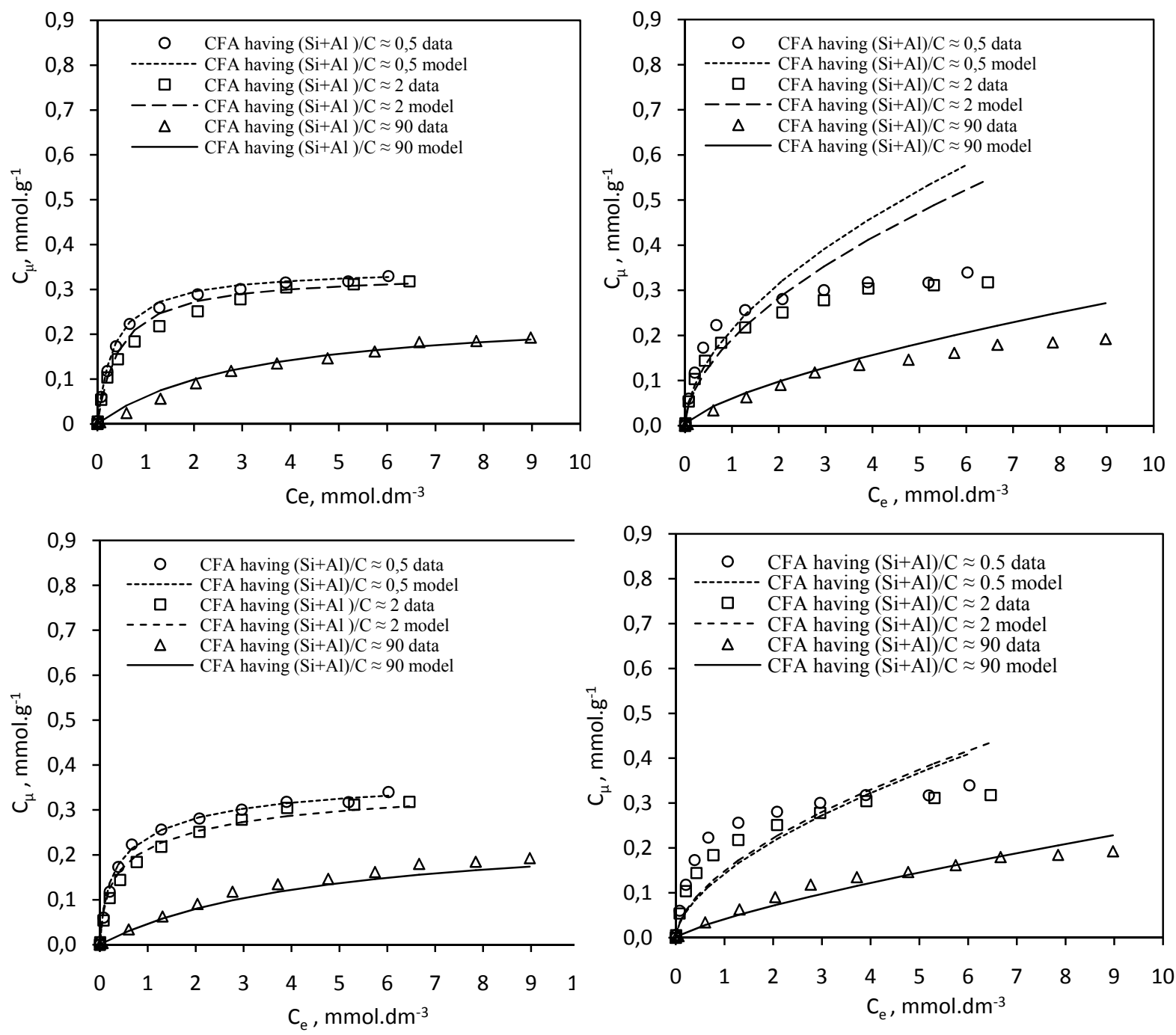
Table 5 Average deviation of $\mathrm{C}_{\mu}$ model toward $\mathrm{C}_{\mu}$ data

\begin{tabular}{ccccc}
\hline & & \multicolumn{3}{c}{ Average deviation of $\mathrm{C}_{\mu}$ model toward $\mathrm{C}_{\mu}$ data $(\%)$} \\
\cline { 3 - 5 } & & {$[\mathrm{Si}+\mathrm{Al}] / \mathrm{C} \approx 0.5$} & $\mathrm{C} \approx 2$ & {$[\mathrm{Si}+\mathrm{Al}] / \mathrm{C} \approx 90$} \\
\hline $1^{\text {st }}$ & model & 4.2 & 5.9 & 9.2 \\
$2^{\text {nd }}$ & model & 33.8 & 22.6 & 30.1 \\
$3^{\text {rd }}$ & model & 5.0 & 7.0 & 15.5 \\
$4^{\text {th }}$ & model & 29.9 & 25.2 & 13.7 \\
$5^{\text {th }}$ & model & 4.8 & 6.3 & 9.7 \\
$6^{\text {th }}$ & model & 8.3 & 8.9 & 13.9 \\
\hline
\end{tabular}

Data in Table 6 shows that the values of $\mathrm{C}_{\mu \mathrm{m}}$ and $\mathrm{K}_{\mathrm{L}}$ are affected by $[\mathrm{Si}+\mathrm{Al}] / \mathrm{C}$ ratio in $\mathrm{CFA}$. The increase of [Si+Al]/C ratio causes a decrease of the values of $\mathrm{q}_{\mathrm{m}}$ and $\mathrm{K}_{\mathrm{L}}$ values because the amount of unburned carbon in CFA decreases.

Table 6 The values of $\mathrm{C} \mu \mathrm{m}$ and $\mathrm{KL}$ for 1 st model

\begin{tabular}{lll}
\hline$[\mathrm{Si}+\mathrm{Al}] / \mathrm{C}$ ratio of CFA & $\mathrm{C}_{\mu \mathrm{m}}\left(\mathrm{mmol} \cdot \mathrm{g}^{-1}\right)$ & $\mathrm{K}_{\mathrm{L}}\left(\mathrm{dm}^{3} \cdot \mathrm{mmol}^{-1}\right)$ \\
\hline 0.5 & 0.3423 & 2.8860 \\
2 & 0.3398 & 0.9259 \\
90 & 0.2753 & 0.2588 \\
\hline
\end{tabular}

\section{Conclusion}

It is concluded that CFA having high unburned carbon content has high adsorption capacity. The Langmuir model (1 st model) yielded excellent fit with equilibrium data because the adsorption of benzene only occurs on unburned carbon. The values of $\mathrm{C}_{\mu \mathrm{m}}$ and $\mathrm{K}_{\mathrm{L}}$ are affected by $[\mathrm{Si}+\mathrm{Al}] / \mathrm{C}$ ratio in $\mathrm{CFA}$. The increase of $[\mathrm{Si}+\mathrm{Al}] / \mathrm{C}$ ratio causes a decrease of $\mathrm{C}_{\mu \mathrm{m}}$ and $\mathrm{K}_{\mathrm{L}}$ values.

\section{Acknowledment}

We are grateful to Directorate for Research and Community Service, Directorate General of Higher Education, Ministry of National Education Republic Indonesia and Gadjah Mada University for doctorate research grant with grant number lppmugm/1200/2009.

\section{References}

[1] Sukandarrumidi. (2006). Batubara dan Pemanfaatannya. Yogyakarta: Gadjah Mada University Press.

[2] Kolemen, S., Acarah, N.B., Tugrul, N., Derun, E.M., Piskin, S. (2013). The zinc adsorption study by using orhaneli fly ash. Water Air Soil Pollut, 224,1366-1376.

[3] Hwang, J.Y., Sun, X., Li, Z. (2002). Unburned carbon from fly ash for mercury adsorption : I. separation and characterization of unburned carbon. Journal of Minerals and Materials Characterization \& Engineering, 1(1), 39-60.

[4] Liang, C., Chen, Y.J. (2010). Evaluation of activated carbon for remediating benzene contaminant : adsorption and oxidative regeneration. Journal of Hazardous Materials, 182, 544-551.

[5] Lin, K.H., Chen, C.Y., Choa, C.G. (2006). Adsorption characteristics of benzene on biosolid adsorbent and commercial activated carbons. J. Air \& Waste Manage. Assoc., 56, 591-600, 2006.

[6] Astuti, W., Wahyuni, E.T.W., Prasetya, A., Bendiyasa, IM. (2012). The effect of coal fly ash treatment with $\mathrm{NaOH}$ on the characters and adsorption capacity toward $\mathrm{Pb}$ (II) in the solution. J.Chem.Chem.Eng., 6(1), 31-38.

[7] Potgieter, J.H., Bada, S.O., Vermaak, S.S.P. (2009). Adsorptive removal of various phenols from water by south african coal fly ash. Water $S A$., 35, 89-96. 